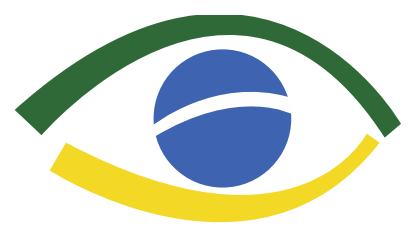

Observatório da lurisdiçãa
Constitucional
Observatório da Jurisdição Constitucional. Ano 6, no. 2, jul./dez. 2013. ISSN 1982-4564.

\title{
A garantia constitucional contra a despedida arbitrária e sem justa causa e o problema da regulamentação judicial de cláusulas constitucionais de eficácia limitada ante a omissão legislativa.
}

Fernando Hugo R. Miranda *

Resumo: Com a ampliação da prática da regulamentação judicial de cláusulas constitucionais de eficácia limitada, é possível identificar situações nas quais a atuação judicial opera a criação de institutos de significados incompletos e assistemáticos. Tal é o que se passa com a regulamentação errática da proteção contra a despedida arbitrária ou sem justa causa, prevista no artigo $7^{\circ}$, inciso $\mathrm{I}$, da Constituição da República. A jurisprudência consolidada, embora tenha se debruçado sobre aspectos de grande importância e efetivamente não endereçadas pelo legislador, por fazê-lo por meio do necessariamente indutivo processo judicial, acabou por criar figuras que não se comunicam entre si e não são capazes de operar a formulações completas e claras, passíveis de observância previsível e institucional pela sociedade.

Palavras-chave: Direito Constitucional; Direito do Trabalho; despedida arbitrária ou sem justa causa; cláusula de eficácia limitada; omissão legislativa; regulamentação judicial; efeitos colaterais.

\begin{abstract}
Although Brazilian Law is centered in the force of statutes, the courts are increasingly ruling cases based on non-self executing constitutional provisions, for lawmakers have not been presenting the necessary regulating bills. As this judicial practice goes stronger, unintended consequences become more usual, once the rulings are not comprehensive enough, addressing just small features of a bigger picture. This phenomenon can be observed in the event of the regulation of the arbitrary and unjustified dismissal, a situation of judicial legislation where one can identify legal inconsistencies.
\end{abstract}

Keywords: Constitutional Law; Labor Law; arbitrary and unjustified dismissal; non-self executing constitutional provisions; legislative void; judicial legislation; unintended consequences.

\footnotetext{
* Doutorando e Mestre em Direito do Trabalho pela Universidade de São Paulo. Mestre em Droit et Sciences du Travail Européen, pela Université de Toulouse 1 - Capitole. Professor de Direito do Trabalho do UniCeub. Advogado.
} 


\section{Introdução.}

É possível afirmar que a valorização dos princípios constitucionais na aplicação judicial dos direitos é, nos últimos tempos uma realidade na prática judicial, sem que daí decorram grandes controvérsias. Como ilustram as palavras de Paulo Bonavides, vivemos a fase do pós-positivismo caracterizada pela "passagem dos princípios da especulação metafísica e abstrata para o campo concreto e positivo do Direito"1.

Para um exemplo de destaque, basta relembrar que o Supremo Tribunal Federal (STF), acolhendo a pretensão formulada no Mandado de Injunção (MI) n $n^{\circ} 712 / \mathrm{PA}^{2}$, deixou claro que a inércia do legislador em regulamentar direitos reconhecidos na Carta autorizaria uma intervenção positiva do Judiciário. No caso, foi determinado que, até superveniência da atividade legiferante regulamentadora, deverão ser seguidas as diretrizes determinadas judicialmente.

No caso da greve dos servidores públicos, portanto, o STF, ao expressamente preencher a lacuna regulamentadora, expôs de forma bem delineada o limite lógico-temporal de validade da solução por ele proposta, a ação regulamentadora pelo Congresso Nacional. A decisão, que representou um divisor de águas na jurisprudência da Corte Constitucional, aparentemente se mostrou uma solução institucional de consenso, considerando que mesmo 6 (seis) anos após a deliberação, o Congresso Nacional mantém-se inerte.

Ocorre que nem sempre o preenchimento da lacuna legislativa se passa de forma tão objetiva e clara como se deu no caso invocado. Por vezes, a inércia do legislador reverbera de forma difusa na jurisprudência que, sendo a todo momento chamada a resolver múltiplas, variadas e por vezes imprevisíveis questões concernentes a um determinado instituto não inteiramente regulamentado, acaba por desenvolver soluções esparsas e sem organicidade.

Em tais situações, em que a ligação entre a lacuna legislativa e a atividade integradora do Judiciário não se apresenta de forma explícita, um grave problema de coerência do direito se evidencia: o desenvolvimento errático e contraditório de institutos jurídicos. A situação não pode e não deve ser subestimada. Grande parte da legitimidade da atuação das instituições no Estado de Direito, ou justiça formal, para relembrar os termos de John Rawls, dependerá de sua capacidade de assegurar expectativas legítimas dos indivíduos,

\footnotetext{
${ }^{1}$ BONAVIDES, Paulo, Curso de Direito Constitucional, 15 a ed. São Paulo: Ed. Malheiros, 2004, p. 294.

${ }^{2}$ Brasil, STF, MI 720/PA, Tribunal Pleno, Rel. Min. Eros Grau, j. 25/10/2007, DJe 31/10/2008.
} 
sendo certo que a "a inevitável imprecisão das leis em geral e ampla gama permitida para sua interpretação encorajam uma arbitrariedade na tomada de decisões que apenas uma submissão à justiça pode debelar"3.

O que pretendo demonstrar é que a imperdoável falha do legislador em proceder à regulamentação adequada de direitos constitucionais, muitas vezes decorrentes de movimentos políticos calculados, deve encontrar no Judiciário um espaço de crítica e resistência, e não de reconforto. A divisão dos três poderes não se sustenta apenas no respeito mútuo às prerrogativas e competências de cada um deles, mas inclusive, e talvez, sobretudo, na própria estruturação de seus meios e possibilidades de ação. Pretender que o Judiciário regule institutos jurídicos de forma adequada, previsível e segura pode ser um erro comparável a esperar um julgamento técnico do plenário do Parlamento.

Para endereçar a exposição e o enfrentamento desse problema, proponho um estudo de caso em torno da norma inscrita no artigo $7^{\circ}$, inciso I, da Constituição, que versa sobre a proteção contra despedida arbitrária ou sem justa causa, que ainda aguarda, nas comemorações dos 25 anos da Carta, a lei complementar que a regulamentará. Ao percorrer a saga nacional que acompanha a questão, desde antes da Constituição de 1988, tentarei demonstrar que a inércia legislativa importou em repercussões jurisprudenciais inesperadas, já que, embora derivadas do vácuo em alguma medida, não se desenvolveram explicitamente à luz do artigo $7^{\circ}$, inciso I, da Carta.

\section{O sentido do artigo $7^{\circ}$, inciso $\mathbf{I}$, da Constituição da República quando de sua promulgação. Uma rápida digressão histórica.}

Segundo o texto originário da Consolidação das Leis do Trabalho, que entrou em vigor no dia $1^{\circ}$ de maio de 1943 , a mitigação legal do poder do empregador de encerrar a relação contratual trabalhista se dava a partir de uma dupla elaboração, a depender da duração do contrato de trabalho ${ }^{4}$. Para as relações duradoras, que contassem com mais de 10 (dez) anos completos, era garantida ao trabalhador a denominada estabilidade decenal, retirando do

\footnotetext{
${ }^{3}$ RAWLS, John, Uma teoria da Justiça. São Paulo: Ed. Martins Fontes, 2000, pp. 62-63.

${ }^{4}$ Não é demais mencionar que a Constituição de 1937, então em vigor, referia, no artigo 137, alínea $f$, como garantia geral mínima, uma indenização proporcional aos anos de serviços, excepcionando as hipóteses de leis prevendo a estabilidade, como ocorria de fato com algumas categorias, como a dos ferroviários (art. 42 do Decreto Legislativo no 4.682, de 1923).
} 
empregador o poder de extinguir o contrato de trabalho, salvo por justa causa ou motivo de força maior ${ }^{5}$. Antes de completados os dez anos, as demissões poderiam se dar por livre e discricionária iniciativa do empregador, sendo devida, no entanto, uma indenização no valor da remuneração mensal do empregado para cada ano trabalhado ${ }^{6}$.

Após vinte e três anos de vigência do modelo, a disposição foi substancialmente alterada quando da instituição do Fundo de Garantia do Tempo de Serviço (FGTS), o que se passou por meio da edição da Lei $n^{\circ} 5.107 / 66$. Pela inovação, os empregados poderiam ser demitidos por livre iniciativa do empregador, independentemente do tempo de serviço. Em contrapartida, o empregador passaria a depositar em um fundo vinculado ao empregado, de movimentação condicionada à observância de certos critérios legais, o percentual de $8 \%$ da remuneração mensal do trabalhador. Além disso, na ocasião de eventual despedida sem justa causa, o empregador deveria depositar, a título de indenização pela despedida, o percentual de $10 \%$ sobre os valores contabilmente devidos ao FGTS no período do contrato de trabalho ${ }^{7}$.

Na prática, a instituição do FGTS teve duas repercussões práticas, vigentes até hoje. A primeira foi o abandono da premissa de proteção baseada na mitigação do poder do empregador de pôr fim ao contrato de trabalho, limitada que foi ao desestímulo econômico decorrente do pagamento de indenização ao final do contrato. Do ponto de vista do empregado, o que se passou foi tão só a extensão do modelo indenizatório previsto no artigo 478 da CLT para todos as hipóteses de demissão, independentemente do tempo de serviço, já que $8 \%$ sobre os treze salários devidos ao trabalhador anualmente contabilizam, no período, exatos $104 \%$ do valor de uma remuneração mensal. A novidade, portanto, representou um acréscimo real de algo em torno de $14 \%$ em relação à indenização anteriormente prevista, o que se deu em troca da estabilidade decenal.

A segunda foi a instituição de um fundo público que, se por um lado representa um aumento compulsório da remuneração contratual ou mínima do empregado em $8 \%$ (oito por cento), por outro liga, à parcela, interesses governamentais de elevado significado. O FGTS, ao captar $8 \%$ de toda a massa salarial formal do país, remunerando o preço ali depositado de forma extremante desvantajosa em relação a qualquer outro investimento disponível no mercado, tornou-se um ativo que governo algum parece disposto a abrir mão.

\footnotetext{
${ }^{5}$ Artigo 492 da CLT.

${ }^{6}$ Artigo 478 da CLT.

${ }^{7}$ Artigo $6^{\circ}$ da Lei 5.107/66.
} 
Em termos gerais ${ }^{8}$, portanto, a experiência nacional até 1988 passou por duas formas de proteção em relação à extinção do contrato de trabalho: $i$ ) a mitigação jurídica do poder de o empregador extinguir o contrato, que se dava por meio da estabilidade (proteção jurídica); ii) a criação de desestímulos econômicos à demissão, o que se dava pela indenização (proteção econômica). Some-se à equação o interesse governamental na manutenção do FGTS, o que, ao menos da perspectiva histórica, punha-se em confronto com eventual interesse ao retorno de uma proteção jurídica como a estabilidade.

A constituinte de 1987/1988 teve de tratar com essa oposição histórica entre FGTS e a estabilidade. A resposta de primeira hora foi, tão simplesmente, superar o fundamento político da criação do Fundo - extinção da estabilidade - e restaurar a estabilidade com a manutenção do FGTS. A ideia, portanto, seria relançar o FGTS como um direito do trabalhador, autônomo em relação ao debate quanto à forma de proteção da continuidade do contrato de trabalho. Nessa empreitada, por motivos óbvios, trabalhadores e governo tinham interesses compartilhados.

Já no Anteprojeto Afonso Arinos, foi simplesmente reconhecido o direito "à estabilidade no emprego e fundo de garantia do tempo de serviço", sem explicação alguma de como isso se passaria ${ }^{9}$. O mesmo se passou nos debates da Subcomissão dos Direitos dos Trabalhadores e Servidores Públicos. Embora alguns integrantes tenham sugerido que seria necessária a realização de uma escolha entre o FGTS e a estabilidade, o texto finalmente proposto pela maioria contemplava a manutenção de ambas as figuras como direitos autônomos do trabalhador ${ }^{10}$.

\footnotetext{
${ }^{8}$ Considerando o escopo do presente estudo, alguns aspectos relevantes, mas estranhos ao corte proposto, deixaram de ser mencionados, como, por exemplo, a figura da despedida obstantiva (S. 26/TST) e a possibilidade de opção do FGTS (art. $1^{\circ}$ da Lei $\mathrm{n}^{\circ}$ 5.107/66), definitivamente extinta apenas com o advento da Constituição, mas em desuso muito antes desse marco.

${ }^{9}$ Art. 343, inciso XVI, do texto do projeto (Diário Oficial, 26 de setembro de 1986, Suplemento Especial ao no 185).

${ }^{10}$ Ver ata da $6{ }^{a}$ Reunião Ordinária da Comissão da Ordem Social, Subcomissão dos Direitos dos Trabalhadores e Servidores Públicos para as posições dos constituintes sobre a dicotomia estabilidade e FGTS, ou a ausência dela. Na $24^{\mathrm{a}}$ Reunião Ordinária foi aprovado o texto relativo à estabilidade, que dispunha: "Estabilidade desde a admissão no emprego, salvo o cometimento de falta grave comprovada judicialmente, facultado o contrato de experiência de 90 dias". Igualmente, foi confirmado o direito ao FGTS: "Fundo de Garantia do Tempo de Serviço que poderá ser levantado pelo trabalhador, em qualquer caso, sobre o contrato de trabalho" (fls. 321 da íntegra das atas). Não é demais mencionar que o direito ao FGTS foi também estendido aos servidores públicos, a demonstrar, em defintivo, o entendimento da Subcomissão sobre a independência entre o FGTS e a estabilidade (fls. 337 da íntegra das atas).
} 
Coube à comissão de sistematização alterar o texto enviado pela Comissão da Ordem Social, aproximando-o da versão prevalecente. Nela, a discussão ficou limitada à existência ou não de estabilidade, tendo sido fixado o direito ao "contrato de trabalho protegido contra despedida imotivada sem justa causa, nos termos da lei"11.

O texto final resultou de um acordo de líderes, no qual foi substituída a expressão despedida imotivada por despedida arbitrária, remetendo-se à regulamentação posterior a ser realizada por lei complementar que asseguraria, como proteção, uma indenização compensatória, entre outros direitos.

Art. $7^{\circ}$ São direitos dos trabalhadores urbanos e rurais, além de outros que visem à melhoria de sua condição social:

I - relação de emprego protegida contra despedida arbitrária ou sem justa causa, nos termos de lei complementar, que preverá indenização compensatória, dentre outros direitos.

Pelo texto final, portanto, foi definido que a proteção se resolveria posteriormente. Garantiu, no entanto, que, dentre as alternativas de regulamentação possíveis, a proteção econômica deveria necessariamente ser contemplada de alguma forma. Em reforço à opção, decidiu, desde já, que o modelo de proteção transitório seria o de pagamento de uma indenização, cuja base de cálculo seria o FGTS, conforme art. 10, inciso I, do ADCT.

Esta breve digressão histórica tem por escopo explicitar dois aspectos. O primeiro é que, segundo a experiência da legislação nacional até 1988, as despedidas por iniciativa do empregador eram divididas em com justa causa e sem justa causa, sendo que esta última também era denominada como despedida arbitrária ou despedida imotivada ${ }^{12}$. A segunda é a de que, embora o FGTS tenha historicamente surgido como uma substituição ao modelo da proteção jurídica, após a Carta foi aberta a possibilidade de sua concomitância, já que o FGTS foi erigido como direito do trabalhador e, apenas circunstancialmente, indicado como base de cálculo da indenização a ser conferida pela despedida arbitrária ou sem justa causa, até a edição da referida lei complementar regulamentadora.

\footnotetext{
${ }^{11}$ Ata da Comissão de Sistematização, Diário da Assembleia Nacional Constituinte, Suplemento C, pp. 329-376. O texto foi mantido após a rejeição de variados destaques, visando assegurar a estabilidade.

12 Quando muito, os autores, ante a invocação do artigo 165 da CLT, definiam a despedida arbitrária como aquela realizada sem motive disciplinar, técnico, econômico ou financeiro, ou seja, sem justa causa. Ver, por todos, BARROS, Alice Monteiro de. Curso de Direito do Trabalho. São Paulo: Ed. LTr, 2005, p. 920.
} 


\section{O imbróglio da tentativa de regulamentação do inciso I do artigo $7^{\circ}$, CF: a Convenção $n^{0} 158 /$ OIT.}

Passados praticamente 8 (oito) anos da promulgação da Carta, em 1996, o texto ainda não havia sido regulamentado. Diante de tal fato, entendeu o Poder Executivo que a matéria poderia ser regulamentada pela internalização do texto da Convenção $n^{\circ} 158$ da Organização Internacional do Trabalho.

Segundo o texto do tratado multilateral, uma proteção jurídica atenuada em relação à estabilidade era conferida ao contrato de trabalho, por meio da instituição de um inédito requisito para a demissão por iniciativa do empregador, a causa justificada. Por causa justificada deve entender-se um motivo relacionado à capacidade ou comportamento do empregado, ou baseada nas necessidades de funcionamento da empresa ${ }^{13}$.

Ao contrário da despedida por justa causa, que demanda um comportamento proporcionalmente grave e taxativo por parte do empregado, a causa justificada é apresentada, pelo texto, como alternativa à despedida por denúncia vazia, visando principalmente à criação de mecanismos de isonomia de tratamento entre empregados. Tanto é assim que, a par da instituição da causa justificada, é também estabelecido um procedimento para a demissão, que deve contar, no mínimo, com duas etapas: $i$ ) a prévia informação do trabalhador sobre a causa apresentada e ii) e a concessão de oportunidade para sua manifestação ${ }^{14}$. A decisão quanto à demissão, em todo caso, segue do empregador, não sendo necessário procedimento judicial prévio, a exemplo do que se passa com o inquérito judicial para a apuração de falta grave ${ }^{15}$.

A iniciativa evoluiu para um desastre jurídico.

Cumprindo-se o caminho da internalização de tratados internacionais, após a ratificação, foi editado decreto legislativo ${ }^{16} \mathrm{e}$, posteriormente, decreto do chefe do poder executivo, o Decreto ${ }^{\circ} 1.855$, de 10/4/1996.

Reações políticas e jurídicas se seguiram à ratificação. CNT e CNI ingressaram com ADI, tombada sob o $n^{o} 1.480 / \mathrm{DF}$. Afirmou-se, primeiramente, o vício de forma, já que o artigo $7^{\circ}$, inciso I, da CF exige lei complementar para regulamentação da proteção contra a despedida arbitrária e sem justa causa. Em acréscimo, alegou-se que convenção necessitaria

\footnotetext{
${ }^{13}$ Artigo $4^{\circ}$ da Convenção.

${ }^{14}$ Artigo $7^{\circ}$.

${ }_{15}$ Artigos 853 e seguintes da CLT.

${ }^{16}$ Decreto Legislativo ${ }^{\circ}$ 68/92.
} 
de regulamentação, apresentando-se seu texto como meramente programático, além do argumento de que o dispositivo constitucional previra apenas a proteção econômica (indenização), e não jurídica à continuidade do contrato de trabalho. O STF deferiu o pedido liminar para, em síntese, afastar a exegese que venha a ter a convenção como autoaplicável, em julgamento datado de 4/9/1997.

No campo político, o Presidente da República, por meio do Decreto $\mathrm{n}^{\circ} 2100$, de 20/12/1996, denunciou a convenção, oito meses após a publicação de seu texto oficial no Brasil. Posteriormente, o STF entendeu prejudicada a ADI 1.480/DF ${ }^{17}$.

O imbróglio, na verdade, estava apenas começando, e até hoje não teve uma conclusão definitiva.

Contra o decreto de denúncia da convenção, CONTAG e CUT ingressaram com uma ADI, tombada sob o $\mathrm{n}^{\mathrm{o}} 1.625 / \mathrm{DF}^{18}$, questionando a possibilidade de o chefe do executivo, por ato individual, denunciar um tratado internacional cuja recepção foi precedida por ato do Poder Legislativo, o decreto legislativo. O julgamento da ADI 1.625/DF ainda não foi concluído, tendo sido colhidos 4 (quatro) votos até o momento ${ }^{19}$, quando comemoram-se os 25 anos da promulgação da Carta.

O episódio da internalização da Convenção $n^{\circ} 158$ da OIT bem explicita a grande dificuldade dos atores políticos nacionais de lidarem com tópicos delicados do Direito do Trabalho. A exemplo do que se passou na Constituinte, em que a discussão quanto à regulação da matéria foi postergada, e de forma bastante ambígua em relação à dicotomia proteção jurídica/proteção econômica, a tentativa de internalização de um texto internacional, repleto de lacunas e de remissões aos usos de costumes nacionais, efetivamente aponta para a tentativa de resolução da pendência com o mínimo de responsabilização política possível. Não é demais lembrar que, atualmente, busca-se, novamente, a internalização do mesmo texto, com a repetição de todos os equívocos já perpetrados há quase duas décadas ${ }^{20}$.

\footnotetext{
${ }^{17}$ Brasil, STF, ADI 1.480 MC/DF, Tribunal Pleno, Rel. Min. Celso de Mello, j. 04/09/1997, DJ 18/05/2001.

${ }^{18}$ Brasil, STF, ADI 1.625/DF, Tribunal Pleno, Rel. Min. Maurício Corrêa, pendente de julgamento.

${ }^{19}$ Para os Ministros Maurício Corrêa e Carlos Ayres Britto, é necessária a prévia manifestação do Congresso para a denúncia. O Min. Nelson Jobim voltou pela improcedência do pedido, enquanto o Min. Joaquim Barbosa pela total procedência dos pedidos. O julgamento foi suspenso por pedido de vista da Min. Ellen Gracie (informativo $\mathrm{n}^{\circ}$ 549, STF).

${ }^{20}$ Trata-se da mensagem presidencial $\mathrm{n}^{\circ}$ 59, de 14 de fevereiro de 2008, na qual o Presidente da República submete o texto da Convenção $n^{\circ} 158$ da OIT à apreciação do Congresso Nacional.
} 
Do panorama legislativo, portanto, a questão, até a primeira década do Século XXI, se limitou a previsão constitucional - pendente de regulamentação - de uma proteção contra a despedida arbitrária e sem justa causa, necessariamente atrelada a uma proteção econômica, mas aberta a outras modalidades. A incapacidade de manejo da situação por atores políticos, no entanto, abriu o espaço para a atuação mais contundente do Poder Judiciário, o qual, ainda que de forma não-orgânica ou sistemática, vem conferindo substância à proteção contra a terminação do contrato de trabalho, como se passa a demonstrar.

\section{O STF e a dicção dos efeitos da aposentadoria espontânea no contrato de trabalho a partir da exegese do artigo $7^{\circ}$, inciso I, da CF.}

Um primeiro indício de que a inércia legislativa iria abrir espaço à atuação positiva do Judiciário se deu na discussão sobre os efeitos da aposentadoria no contrato de trabalho, no contexto do exame da constitucionalidade do artigo 453, § $2^{\circ}$ da CLT, incluídos pela Lei $n^{\circ}$ 9.528/97. Segundo o dispositivo, o ato de concessão de aposentadoria espontânea importaria na extinção do contrato de trabalho ${ }^{21}$.

O dispositivo teve sua constitucionalidade desafiada pela ADI $\mathrm{n}^{\mathrm{o}} 1721^{22}$, movida, em 1997, em conjunto por partidos políticos (PT, PDT e PCdoB). A discussão se passou ao redor do artigo $7^{\circ}$, inciso I, da CF e o art. 10, inciso I, do ADCT. Alegou-se que o dispositivo, ao atestar que àqueles que se aposentassem espontaneamente teriam o contrato extinto, ofendia à Constituição, que garantia aos demitidos arbitrariamente ou sem justa causa certa proteção, a saber, a proteção econômica prevista no artigo 10, inciso I, do ADCT - indenização de 40\% do FGTS - enquanto outra não fosse especificada por lei complementar.

Desde a primeira hora, com o julgamento, em dezembro de 1997 do pedido cautelar, o STF entendeu pela inconstitucionalidade do dispositivo. O cerne da controvertida decisão encontra-se na definição do que é despedida arbitrária e sem justa causa. Em suma, partiu-se da conceituação do que seria despedida arbitrária e sem justa causa para, em seguida, afirmar que o legislador ordinário não poderia criar uma hipótese de demissão arbitrária e sem justa

\footnotetext{
${ }^{21}$ Eis o texto do dispositivo: " $\$ 2^{\circ} \mathrm{O}$ ato de concessão de benefício de aposentadoria a empregado que não tiver completado trinta e cinco anos de serviço, se homem, ou trinta, se mulher, importa em extinção do vínculo empregatício". O $\S 1^{\circ}$ também é representativo da discussão, mas por razões didáticas, tratarei apenas do $\S$ $2^{\circ}$, que encerra a essência do debate.

${ }^{22}$ Brasil, STF, ADI-1721/DF, Tribunal Pleno, Rel. Min. Carlos Ayres Britto, j. 11/10/2006, DJe 29/06/2007.
} 
causa destituída da indenização prevista no artigo 10, inciso I, do ADCT. Daí, afirmou-se que o $\S 2^{\circ}$, ao determinar que a aposentadoria espontânea importaria a extinção automática do vínculo, estaria a criar uma hipótese de despedida arbitrária ou sem justa causa que não daria ensejo à indenização prevista.

Curiosamente, no entanto, a definição do que seria despedida arbitrária e despedida sem justa causa partiu da leitura do que estabelecido pelo próprio legislador ordinário. A conceituação da despedida sem justa causa decorreu de exame à contrário senso, sendo considerada sem justa causa a despedida que não decorra de justa causa, esta prevista no artigo 482 da CLT. Já a conceituação de despedida arbitrária emanaria do artigo 165 da CLT, o qual, ao tratar sobre a estabilidade de integrantes de comissões internas de prevenção de acidentes, indica ser arbitrária a dispensa não fundada em razões técnicas, disciplinares, econômicas ou financeiras.

Assentadas essas definições, foi afirmado o seguinte:

De considerar-se, pois, arbitrária toda despedida que não se fundar em falta grave ou em motivos técnicos ou de ordem econômico-financeira.

Tais limites que haverão de ser observados pela lei complementar que virá regulamentar o inc. I do art. $7^{\circ}$ da $\mathrm{CF} / 88$ e que, necessariamente, haverá de estabelecer a indenização compensatória e os demais direitos que serão outorgados aos empregados despedidos nas condições apontadas. Pena de ofender a Constituição. ${ }^{23}$

Criou-se, assim, uma tautologia. Mesmo em face de os parâmetros materiais de definição do que seria despedida arbitrária ou sem justa causa terem sido extraídos da legislação ordinária, estes mesmos parâmetros não poderiam ser alterados pelo legislador ordinário. E mais, tais parâmetros deverão, conforme se lê da passagem transcrita, ser observados na lei complementar que virá regulamentar o artigo $7^{\circ}$, inciso $\mathrm{I}$, da $\mathrm{CF}$.

Não se imaginou na decisão, por exemplo, que uma eventual lei complementar poderia, tão simplesmente, definir que as figuras da despedida arbitrária ou da despedida sem justa causa seriam caracterizadas, necessariamente, pela iniciativa do empregador pela extinção do contrato, algo estranho ao contexto da aposentadoria espontânea, de iniciativa do próprio empregado. Tal solução, aliás, seria de todo consentânea com tradição do Direito do Trabalho, e com a lógica, bastante razoável, de que o espírito do dispositivo constitucional

\footnotetext{
${ }^{23}$ Fls. 3 do voto do Relator, Min. Ilmar Galvão, proferido na sessão de julgamento do Tribunal Pleno de 19/12/1997. DJ 11/04/2003.
} 
seria proteger o contrato de trabalho do poder do empregador. Tanto é este o espírito do Direito do Trabalho, que na hipótese legal em que foi conferido ao empregador o poder de ter iniciativa sobre a aposentadoria do empregado ${ }^{24}$, incumbe a este o pagamento da indenização constitucional, a exemplo do que se passa na despedida sem justa causa de sua iniciativa.

Não é demais mencionar, por exemplo, que mesmo países que ratificaram a Convenção $n^{\circ} 158$ da OIT, como Portugal e Espanha, é previsto textualmente que o advento da aposentadoria importa na extinção do contrato de trabalho ${ }^{25}$.

No julgamento definitivo da ADI, ideia semelhante foi utilizada, embora não se tenha buscado na legislação a conceituação dos institutos da despedida arbitrária ou sem justa causa. Exarada em outubro de $2006^{26}$, quando mais em voga a concepção da força normativa dos princípios, partiu-se da premissa de que o conjunto dos princípios da Carta Magna, tal como o valor social do trabalho, aponta no sentido da proteção à continuidade da relação empregatícia. Assim, não seria possível afirmar que a aposentadoria espontânea, porque exercício regular de um direito, poderia importar em um tratamento menos favorável do que a despedida por justa causa, em que o trabalhador é punido por sua conduta inapropriada. Eis a síntese da conclusão, constante dos itens 5 e 6 da ementa:

5. O Ordenamento Constitucional não autoriza o legislador ordinário a criar modalidade de rompimento automático de vínculo de emprego, em desfavor do trabalhador, na situação em que este apenas exercita o seu direito de aposentadoria espontânea, sem cometer deslize algum.

6. A mera concessão da aposentadoria voluntária ao trabalhador não tem por efeito extinguir, instantânea e automaticamente, o seu vínculo de emprego.

A sutileza do argumento levantado no acórdão definitivo não afasta a consideração expendida em relação à decisão cautelar. Mesmo subliminarmente, foi conferido um significado à modalidade arbitrária ou sem justa causa, no sentido de algo contrário à despedida por justa causa. Nesta perspectiva, adotou-se a posição, ainda que implícita, de que o $\S 2^{\circ}$ teria criado uma distinção injustificada e, portanto, discriminatória, ao afastar a indenização mesmo no caso em que o empregado não teria apresentado conduta punível. Nas

\footnotetext{
${ }^{24}$ Art. 51 da Lei $n^{\circ} 8.213 / 91$.

25 Respectivamente, artigo 343 do Código de Trabalho Português e art. 49, item 6, do Estatuto de los Trabajadores da Espanha.

${ }^{26}$ Brasil, STF, Tribunal Pleno, Rel. Min. Carlos Britto, j. 11/10/2006, DJ 29/06/2007.
} 
entrelinhas, o que se lê é que a única exceção possível ao pagamento da indenização seria a despedida por justa causa, sendo vedado até mesmo ao legislador criar hipótese distinta.

No final das contas, a decisão simplesmente retirou das relações privadas a extinção do contrato de trabalho pelo advento da aposentadoria, algo da própria tradição do instituto, como demonstra, por exemplo, a Lei 8.112/90, que regula o regime jurídico estatutário federal $^{27}$ ou próprio caput do artigo 453 da CLT, ignorado na decisão. Sendo o advento da aposentadoria algo indiferente ao contrato de trabalho, será necessário, a cada aposentadoria, perquirir a forma de extinção do contrato, se por iniciativa do empregado ou do empregador, a gerar indefinições mesmo nos casos em que o próprio empregado queira parar de trabalhar, em face da indenização em jogo. Retira-se, ainda, a vantagem pecuniária que teria o empregador em aguardar a aposentadoria de seus empregados, já que será sempre devida a indenização pela dispensa arbitrária ou sem justa causa.

A reflexão sobre o que decidido na ADI 1.721, portanto, demonstra que o STF conduziu o desenvolvimento de sua fundamentação a partir da ausência de uma regulamentação precisa do texto do inciso I do artigo $7^{\circ}$, da Constituição da República, já que ele, em esforço hermenêutico, tratou de conferir significado às expressões. Em ambas as decisões, separadas pelo interregno de quase uma década, o STF precisou conferir significado e conteúdo a expressões que, pela intenção originária, deveriam ser conferidas pelo legislador. No processo, no entanto, descuidou-se do exame da organicidade do instituto, da tradição do direito ou das consequências da decisão.

\section{O TST e a ordem de reintegração por demissão presumidamente discriminatória. A experiência da Súmula 443 do TST.}

As consequências da inação do legislador podem influenciar construções jurisprudenciais as mais diversas, muitas até aparentemente estranhas ao texto que penda de regulamentação. Tal foi o que se passou com a construção, pelo Tribunal Superior do Trabalho, da doutrina em relação às demissões de portadores de doenças que suscitem

\footnotetext{
${ }^{27}$ Art. 33, inciso VII.
} 
estigma social. Para o Tribunal, em tais casos, o direito à reintegração decorre da presunção de tratamento discriminatório, como restou consolidado no enunciado de sua Súmula $443^{28}$.

Como já demonstrado, a proteção à continuidade do contrato de trabalho pode se dar por duas formas: a proteção jurídica, que limita os poderes jurídicos do empregador de extinguir o contrato e a proteção econômica, a qual, impondo ônus financeiros ao ato da despedida sem justa causa de iniciativa do empregador, visa ao seu desestímulo. No panorama constitucional inaugurado pela Carta de 1988, a regra geral adotada foi a proteção econômica, concretizada pela indenização de $40 \%$ do FGTS (ADCT, 10, inciso I), com a definição de hipóteses específicas de proteções jurídicas, sempre temporárias, como se passa com as estabilidades do dirigente sindical, do membro da CIPA e da empregada gestante ${ }^{29}$. A lei ordinária ainda se encarregou de criar outras hipóteses de estabilidade, como se passa com a estabilidade acidentária ${ }^{30}$.

A proteção jurídica, ao garantir ao empregado um tempo fixo e determinado de manutenção do contrato de trabalho, em típica disposição de ordem pública, impossibilita toda e qualquer iniciativa do empregador de impedir o gozo de tal direito pelo trabalhador, salvo as hipóteses legais, como a falta grave. Isso quer dizer, portanto, que todas as ações que atentem contra a regular fruição do direito à manutenção do contrato no período serão destituídas de eficácia, do que nasce por exemplo, a possibilidade de reintegração quando de eventual despedida não amparada nas exceções legais.

A legislação trabalhista nacional, no entanto, nada dispõe sobre despedidas fundadas em razões discriminatórias, ao contrário do que ocorre em outros países ${ }^{31}$. O TST, assim, construiu a jurisprudência a partir da valoração dos princípios constitucionais da igualdade e da dignidade da pessoa humana, como é possível concluir do exame dos precedentes

${ }^{28}$ DISPENSA DISCRIMINATÓRIA. PRESUNÇÃO. EMPREGADO PORTADOR DE DOENÇA GRAVE. ESTIGMA OU PRECONCEITO. DIREITO Å REINTEGRAÇÃO - Res. 185/2012, DEJT divulgado em 25, 26 e 27.09.2012. Presume-se discriminatória a despedida de empregado portador do vírus HIV ou de outra doença grave que suscite estigma ou preconceito. Inválido o ato, o empregado tem direito à reintegração no emprego.

${ }^{29}$ Respectivamente, artigos $8^{\circ}$, inciso VIII, da Constituição e artigo 10, inciso II, alíneas $a$ e $b$ do ADCT.

${ }^{30}$ Artigo 118, da Lei n ${ }^{\circ} 8.213 / 91$.

${ }^{31}$ Como exemplo, é possível mencionar o Código do Trabalho francês, que, ao enunciar expressivo rol de vedação quanto às discriminações, donde se lê o estado de saúde (état de santé), no art. L-1132-1, determina que toda disposição ou ato discriminatório serão nulos (L-1132-4). Estêvão Mallet menciona, ainda, a lei federal mexicana, que se refere, em seu artigo $4^{\circ}$, a "condiciones de salud" (MALLET, Estêvão. Igualdade e Discriminação em Direito do Trabalho. São Paulo: Ed. LTr, 2013, p. 65). 
indicados pelo Tribunal como justificadores da Súmula $n^{\circ} 443^{32}$. Casos há, inclusive, em que restou expressamente consignado que a dispensa de portador de HIV representaria uma dispensa arbitrária e discriminatória ${ }^{33}$.

A racionalidade dos precedentes é inequívoca. Atos jurídicos fundados em discriminações injustificadas são inválidos, conforme atesta o Código Civil, ao ter por nulos negócios jurídicos cujos motivos sejam ilícitos ${ }^{34}$. Ocorre que a Súmula 443/TST foi além do que emanado dos precedentes que, segundo o Tribunal, lhe dão apoio. Enquanto neles é afirmado que a verificação em concreto de motivação discriminatória torna ilícito o ato, na Súmula é adotada uma definição apriorística, geral e abstrata, de um suporte fático específico a configurar o ato discriminatório.

Segundo o texto do verbete, a despedida de todo portador de HIV ou de outra doença que importe em estigma social é inválida, cabendo ao empregador o inusitado ônus da prova negativa em relação à não-discriminação. Em verdade, o efeito da súmula, da forma em que foi redigida e vem sendo aplicada pelos tribunais pátrios, encerra uma orientação de política pública, na qual ao empregador é imputado o risco social próprio de tais doenças. Em outras palavras, o empregador torna-se obrigado a garantir o contrato de trabalho daqueles que, em decorrência do estigma social que grava seu estado de saúde, terão grandes dificuldades para conseguir uma eventual recolocação no mercado.

A responsabilização, aqui, é mais severa do que a responsabilidade objetiva, visto que sequer é averiguado se as condições de trabalho concorreram como causa para o desenvolvimento da doença. A responsabilidade objetiva, advinda de lei, decorre da concepção do risco criado. É dizer, quando a atividade de alguém gerar um risco a terceiros, é devida a reparação independentemente da demonstração de culpa ${ }^{35}$. Segundo a construção do Tribunal, no entanto, sequer há necessidade de demonstração de qualquer relação entre a atividade do empregador e a doença desenvolvida pelo empregado. O nexo da causalidade, imprescindível à responsabilização objetiva, é irrelevante para a constituição da obrigação do empregador de não demitir o empregado.

\footnotetext{
${ }^{32}$ Ver, por todos, o julgamento proferido no TST-E-ED-RR-76089/2003-900-02-00, SBDI-1, Rel. Min. Rosa Weber, DJ 30/11/2007.

${ }^{33}$ TST-E-RR-366/2000-021-15-00, SBDI-1, Rel. Min. Horácio Senna Pires, DJ 14/11/2008.

${ }^{34}$ Art. 166, inciso III, do CCB.

${ }^{35}$ GONÇALVES, Carlos Roberto. Direito Civil Brasileiro, Volume IV, Responsabilidade Civil. $4{ }^{\mathrm{a}}$ ed. São Paulo: Ed. Saraiva, 2007, p. 31.
} 
Trata-se, pois, verdadeiramente, de nova alocação do risco social, que se desloca do princípio da solidariedade, nos termos da legislação previdenciária, e é privatizado, imputando-o diretamente ao tomador do serviço do momento do conhecimento da doença. $\mathrm{O}$ reconhecimento explícito deste deslocamento do risco social é já verificável em diversos pronunciamentos judiciais, como se lê do seguinte, oriundo do TRT da $3^{\text {a }}$ Região $^{36}$ :

A Súmula supra transcrita encontra amparo nos princípios da dignidade da pessoa humana e dos valores sociais do trabalho, tendo em vista a notória dificuldade que esses trabalhadores encontram para a sua recolocação no mercado de trabalho.

(...)

A propósito, cumpre salientar que a empresa privada não se encontra em campo neutro, quando se trata de promover meios de sobrevivência digna ao trabalhador, de forma que possa simplesmente relegar ao Poder Público o dever de prestar assistência social. Invocase aqui o princípio da função social da propriedade, que também deve ser aplicado no âmbito juslaboral.

(...)

Embora não haja ainda lei específica a garantir a estabilidade dos portadores de "aids", o intérprete deve buscar outras fontes de direito que possam garantir ao trabalhador o seu direito ao emprego. Nesse contexto, à míngua de legislação específica e diante do que dispõem os arts. $4^{\circ}$ da LICC e $8^{\circ}$ da CLT, reputo plenamente cabível a aplicação analógica da Lei 9.029/95 como medida de concretização da ordem constitucional vigente (artigos $1^{\circ}$, III e IV, $3^{\circ}$, I e IV, $7^{\circ}$, XXXI e 170), afastando, por conseguinte, a alegada violação ao princípio da legalidade.

O princípio da solidariedade, informador da proteção social, é baseado exatamente na superação da concepção de que bastaria "dar a cada um o que é seu para que a sociedade fosse justa", adotando-se a ideia de que é preciso dar a "cada um o que não é seu" como medida para reduzir injustiças advindas do risco social. Ocorre que a única forma de compatibilizar tal concepção com o princípio da propriedade é o de estabelecer regras de cotização coletivas voltadas a benefícios específicos, objeto e fim do Direito Previdenciário. O estabelecimento de uma tal proteção por meio de imposição, judicial, de deveres a particulares não previstos na legislação causa grandes perplexidades, e certamente consequências não desejadas na aplicação do entendimento.

\footnotetext{
${ }^{36}$ TRT-3 $^{\text {a }}$ Região, RO-0002074-15.2011.5.03.0040, 6 ${ }^{\text {a }}$ Turma, Rel. Desembargador Anemar Pereira Amaral, DJ 22/10/2012.

${ }^{37}$ RUSSOMANO, Mozart Victor apud CASTRO, Carlos Alberto Pereira de Castro e LAZZARI, João Batista. Manual de Direito Previdenciário, $11^{\mathrm{a}}$ ed. Florianópolis: Ed. Conceito Editorial, 2009, p. 34-35.
} 
Uma delas é a criação de um fator de díscrimen de questionável validade, quando verificado que a presunção de discriminação funda-se na ideia de que os trabalhadores portadores de doenças gravadas por estigma social terão grandes dificuldades para a recolocação no mercado de trabalho. E por qual motivo outros empregados, com iguais ou menores condições de realocação no mercado não usufrem de igual proteção? O que dizer, por exemplo, de empregados portadores de deficiências, empregados sem qualificação profissional adequada ou empregados em idade avançada?

$\mathrm{O}$ questionamento pode parecer exagerado à primeira vista, mas justifica-se quando verificada a abrangência que está sendo dado ao conceito de estigma social, como no caso da glaucoma. No caso, embora tenha sido afirmado pelo TRT-9 inexistir prova da discriminação, o TST, por entender que o ônus da prova demonstrar a não-discriminação era do empregador, afirmou o tratamento discriminatório e determinou a reintegração ${ }^{38}$.

Como leciona Celso Antônio Bandeira de Mello, não é qualquer diferença, conquanto real e logicamente explicável, que possui suficiência para discriminações legais, é preciso que o vínculo demonstrável seja constitucionalmente pertinente ${ }^{39}$. A pertinência constitucional, no caso da criação de garantias de emprego é, precisamente, a proteção inscrita no artigo $7^{\circ}$, inciso I, da Carta. A criação de garantias pela articulação direta de princípios constitucionais de valor, portanto, representa um grande risco.

A exemplo do que antevisto no episódio do STF, acerca dos efeitos da aposentadoria espontânea no contrato de trabalho, pois, a inércia do legislador abriu espaço para que o Poder Judiciário, interpretando princípios constitucionais, desse mais um passo em relação à condensação da carga obrigacional em relação à proteção à continuidade do contrato de trabalho.

O caráter aditivo da jurisprudência é marcante, na medida em que ela encerra, verdadeiramente, uma política pública em relação à proteção social daqueles que, independetemente das condições de trabalho, tiveram o infortúnio de contraírem doença que importará em dificuldade para novas colocações. Não há fundamento infraconstitucional que ampare o contexto obrigacional criado, tratando-se de implementação de valores políticos

\footnotetext{
${ }^{38}$ TST-RR-1996700-79.2006.5.09.0011, $7^{\mathrm{a}}$ Turma. Rel $^{\mathrm{a}}$ Min $^{\mathrm{a}}$ Delaíde Miranda Arantes, DJ 16/08/2013.

${ }^{39}$ MELLO, Celso Antônio Bandeira de. Conteúdo jurídico do princípio da igualdade, $3^{\mathrm{a}}$ ed. São Paulo: Ed. Malheiros, 2006, p. 42.
} 
lastreados na invocação dos valores sociais do trabalho e no princípio da dignidade da pessoa humana.

Houvesse o legislador oferecido uma legislação precisa, em que os contornos das possibilidades de reintegração ao contrato de trabalho fossem melhor definidas e explicitadas, seria naturalmente reduzido o espaço de inovação jurisprudencial.

Não é por acaso, aliás, que em muitos julgados é possível se verificar a utilização da expressão despedida arbitrária, termo utilizado no inciso I do artigo $7^{\circ}$ da Constituição para indicar o objeto da proteção a ser conferida pela ainda por vir lei complementar.

\section{O TST, o STF e a nova figura da despedida sem justa causa motivada.}

É possível, ainda, apontar uma última inovação jurisprudencial ligada à proteção à continuidade do contrato de trabalho, desta vez, fruto da jurisprudência conjunta do TST e do STF e voltada a um requisito de forma inédito no país. Trata-se da análise quanto aos requisitos do ato administrativo relativo à despedida do empregado público, ocupante de vaga em empresas integrantes da Administração Pública Indireta.

A questão se iniciou pela jurisprudência do TST. Entendendo desproporcional a proteção conferida à Empresa de Correios e Telégrafos (ECT), beneficiária de vários dos privilégios próprios do erário, como execução por precatório, o Tribunal passou a exigir da empresa que motivasse as despedidas, ante ao argumento de que elas configurariam típico ato administrativo. O entendimento foi cristalizado da Orientação Jurisprudencial no 247 , item II, da SBDI- $1^{40}$. O mesmo verbete, no entanto, em seu item I, destacava que o mesmo não se passava com as demais empresas integrantes da Administração Pública Indireta, que seguiam livres para operar despedidas sem justa causa e imotivadas.

O ponto de maior relevância da jurisprudência decorre do caráter inovatório da figura criada. Até o advento da OJ 247, despedida imotivada e despedida sem justa causa

40 OJ-SDI1-247 SERVIDOR PÚBLICO. CELETISTA CONCURSADO. DESPEDIDA IMOTIVADA. EMPRESA PÚBLICA OU SOCIEDADE DE ECO-NOMIA MISTA. POSSIBILIDADE (alterada - Res. ${ }^{\circ}$ 143/2007) - DJ 13.11.2007.

I - A despedida de empregados de empresa pública e de sociedade de economia mista, mesmo admitidos por concurso público, independe de ato motivado para sua validade;

II - A validade do ato de despedida do empregado da Empresa Brasileira de Correios e Telégrafos (ECT) está condicionada à motivação, por gozar a empre-sa do mesmo tratamento destinado à Fazenda Pública em relação à imunidade tributária e à execução por precatório, além das prerrogativas de foro, prazos e custas processuais. 
representavam sinônimos, sendo o termo "imotivado" utilizado no sentido da inexistência de fundamento fático para a extinção do contrato. Ambas, tanto a despedida imotivada, quanto a despedida sem justa causa, se opunham hermeneuticamente à despedida por justa causa, ou seja, aquela fundada em comportamento infracional do empregado (aspecto fático), devidamente previsto em lei.

A distinção, efetivamente, é de uma grande importância para a técnica jurídica. Rigorosamente, até mesmo a despedida por justa causa, em nosso ordenamento jurídico, é imotivada, na medida em que o empregador, também nessas hipóteses, não está obrigado a apresentar previamente ao empregado as razões que o levaram a considerar a ocorrência da imputada conduta inapropriada. Apenas em juízo, em eventual reclamação trabalhista, terá o empregador que apresentar as razões da despedida por justa causa, oferecendo as provas que a embasam, recaindo sobre si o ônus da prova.

Assim, enquanto a dicotomia motivado/imotivado traduz preocupação quanto à forma, a dicotomia por justa causa/sem justa causa dirige-se à questão de fundo, acerca da existência ou não de vinculação obrigatória a uma dada fundamentação fática previamente estabelecida pela legislação, como se passa com o artigo 482 da CLT.

Tal distinção, inclusive, é comum aos países que adotam os parâmetros da Convenção no 158/OIT. Exemplo expressivo é a França, na qual é diferenciada a figura da despedida injustificada (licenciement injustifié) da despedida irregular (licenciement irrégulier). Enquanto a primeira se refere a uma falha de conteúdo, onde o empregador despediu um empregado sem apontar uma das causas de mérito, aspecto fático, necessária para tanto, a segunda diz respeito a uma despedida realizada sem o cumprimento do devido processo, no caso, a motivação, ou a explicitação das razões pelas quais o empregado foi demitido.

A exigência formal de motivação serve a um propósito bastante claro, o de reduzir as chances de comportamentos abusivos. Ao motivar o ato, o empregador torna-se vinculado ao fato ali apresentado, não podendo inovar em relação a ele, operando-se a teoria dos motivos determinantes. Submetido a eventual controle judicial, o fato narrado na motivação é o único passível de prova. Com isso, reduzem-se os espaços para comportamentos discriminatórios e abusivos, que são, por sua própria natureza, inconfessáveis. 
O risco da criação da referida diferenciação pela jurisprudência, e não pela legislação, é justamente a confusão gerada na aplicação da figura. Sem tradição jurídica, seja doutrinária, legal ou jurisprudencial, acerca do que seria uma despedida sem justa causa motivada, é bastante previsível que a jurisprudência nacional eleve o rigor do exame das motivações apresentadas, desconsiderando que o fim precípuo da motivação é apenas o de evitar comportamentos abusivos, ou seja, o ato ilícito decorrente do exercício de um direito em excesso manifesto dos limites impostos pelos fins econômicos, sociais, pela boa-fé ou pelos bons costumes ${ }^{41}$.

Em assim sendo, por exemplo, é perfeitamente válida a despedida de empregado da ECT quando verificado, e assinalado na motivação da demissão, que o empregado teria descumprido normas regulamentares da empresa. Não sendo o empregado detentor de estabilidade, e em se tratando de despedida sem justa causa, não caberia exame sobre a gravidade da conduta, a partir do cotejo de elementos outros, como o tempo de serviço do empregado na empresa. Não foi, contudo, o que afirmou o TST ao examinar o caso, porquanto, ao cotejar outros elementos do contrato, sobretudo o tempo de serviço na empresa, entendeu por afirmar nula a demissão, identificando, ainda que de forma implícita, uma desproporção entre a conduta assinalada na motivação e a decisão do empregador ${ }^{42}$, algo que é exigido apenas para despedidas por justa causa.

A previsão da exigência de motivação, da forma como afirmado pelo TST, portanto, embora represente, em si, uma ideia interessante e efetivamente aplicada em outros países, carece de organicidade, representando apenas um meio caminho, uma meia ponte, que não chega a atravessar o rio. Isso porque a instituição do modelo da necessidade de motivação, para que alcance seu objetivo, precisa ser bem explicitada, em todos os seus contornos, fundamentos, e finalidades. A adoção da figura, da forma como realizada, partiu de um fundamento reativo, em face do reconhecimento de privilégios próprios do erário à $\mathrm{ECT}$, o que não é suficiente para apontar um sentido geral à norma.

Essa falta de organicidade, não seria exagerado concluir, chamou a atenção do STF ao se debruçar sobre a questão. No julgamento do RE $\mathrm{n}^{\mathrm{o}}$ 589.998-PI ${ }^{43}$, processado pela sistemática da repercussão geral, a Corte Constitucional examinou justamente recurso da ECT

\footnotetext{
${ }^{41}$ Artigo 187 do Código Civil.

${ }^{42}$ Brasil, TST-RR-752-05.2010.5.03.0101, 6 a Turma, Rel. Min. Aloysio Corrêa da Veiga, DJ 12/04/2013.

${ }^{43}$ STF, Tribunal Pleno, Relator Min. Ricardo Lewandowski, julgamento dia 20/03/2013. DJe 11/09/2013.
} 
oferecido contra aplicação da OJ 247 no TST. Em seu julgamento, cujo o acórdão apenas recentemente foi publicado, novas premissas foram estabelecidas, inclusive no sentido do aperfeiçoamento da organicidade do modelo inaugurado pelo Tribunal do Trabalho.

Em primeiro lugar, o fundamento instituídor da regra da motivação foi alterado. Conforme pareceu ao STF, a resposta reativa do TST às prerrogativas peculiares da ECT não se mostrava íntegro o suficiente, já que, como componente da Administração Indireta, não seria possível atribuir aos seus empregados a estabilidade prevista no artigo $41 \mathrm{da} \mathrm{CF}$, pouco importando as prerrogativas especiais a ela conferidas.

A exigência da motivação, assim, passou a ser fundada no paralelismo decorrente da regra do concurso público. Segundo avaliado, o tratamento isonômico e impessoal decorrente do concurso público só estaria efetivamente garantido se não fosse dado ao administrador das empresas integrantes da Administração Pública Indireta o poder de demitir imotivadamente seus empregados. Admitido o empregado público por concurso público, apenas pela explicitação das razões da demissão seria possível ter-se por válido o ato.

O segundo aspecto de relevância diz respeito à certificação de que a despedida permanece sem causa fática vinculada, ou, dito de outra forma, sem justa causa. Embora se espere que alguma motivação seja conferida, ela não é vinculada a nenhuma causa prédeterminada na legislação. Assim, um empregado poderá ser demitido porque chegou atrasado, se portou de forma requerida ou não atingiu a produtividade esperada. O relevante é que, uma vez indicada a causa, a empresa seja capaz de, em juízo, demonstrar que o fato apontado realmente se passou, não tendo a despedida se passado por alguma razão dissimulada.

A validade da despedida será aferida pela regra da isonomia e impessoalidade, e não por avaliação da gravidade ou proporcionalidade da conduta. Acaso demonstrado que todos os empregados que se atrasem sejam demitidos, nada haverá de inválida em uma tal motivação, já que o mesmo tratamento, independentemente de seu rigor, é conferido de forma indistinta a todos os empregados. A questão foi posta na ementa do acórdão, mas convém transcrever a seguinte passagem do acórdão:

É dizer: que se pretende com o entendimento perfilhado neste voto não é conferir aos empregados das empresas estatais a estabilidade a que se refere o citado art. 41, mas, como consignado acima, assegurar que os princípios da impessoalidade e da isonomia, 
observados no momento da admissão por concurso público, sejam também respeitados por ocasião da dispensa. ${ }^{44}$

Nessa medida, o julgamento do STF esclarece algo que a jurisprudência do TST ainda não havia feito, já que, como demonstrado, não raro a motivação era examinada à luz de juízos de proporcionalidade da gravidade do fundamento adotado, algo que parece estar superado pela diretriz emanda da posição acima.

É preciso reconhecer, no entanto, para evitar análises ingênuas, que tendo a própria exigência da motivação decorrido de criação jurisprudencial, dificilmente os julgadores deixarão de avaliar, em concreto e segundo juízos de razoabilidade muitas vezes baseados em valores pessoais, a proporcionalidade e justificação do ato. Não se olvida da força de tal tentação. No entanto, derivando a regra da motivação do paralelismo com o concurso público, releva lembrar ser irrelevante para qualquer certame o grau de rigor da avaliação: o importante é a certeza de que, brando ou severo o conteúdo das indagações, ela será inequivocamente idêntica a todos os candidatos. Apenas se quebrada a isonomia, por qualquer forma, seria justificada a intervenção judicial.

A decisão do STF, conquanto proferida em autos sujeitos à sistemática da repercussão geral, ainda precisará ser estudada, interpretada e aplicada. Tanto é assim que o TST ainda não procedeu à revisão do item I da OJ 247, que contraria o novo entendimento, não obstante seja possível já identificar arestos da Corte Superior no novo sentido.

A experiência da criação da figura de uma despedida sem justa causa motivada, porque criada por força da jurisprudência, também se apresenta errática e de contornos fluídos e não previsíveis, sendo certo que até mesmo a decisão do STF dá ensejo a interpretações diversas dos contornos aqui apresentados. Esta é, inclusive como se vem tentando demonstrar ao longo do presente estudo, uma limitação institucional que precisa ser reconhecida pelo próprio Poder Judiciário no exercício de preenchimento de lacunas derivadas da inação do legislador.

\section{Conclusão.}

A trajetória da matéria tratada no inciso I do artigo $7^{\circ}$ da Constituição representa um relevante estudo de caso sobre como imprevisíveis podem se revelar as consequências da

\footnotetext{
${ }^{44}$ Fls. 12 do acórdão publicado (8 do voto do Relator, Min. Ricardo Lewandowski).
} 
inércia do legislador em proceder à densifição dos princípios insculpidos na Carta Magna.

Sua história revela, antes de mais nada, uma verdadeira e grave incapacidade política de nossos legisladores para construir o consenso mínimo necessário à regulamentação, e também uma esperança vã em tentar superar a lacuna sem enfrentar de forma direta e precisa os contornos do problema. Em relação a algumas matérias, como a ora referida, tuda leva a crer que a inércia decorra efetivamente de uma ponderada decisão política, baseada nos dividendos eleitorais envolvidos no trato da matéria.

Nesse contexto, o Poder Judiciário foi chamado a dar conteúdo à proteção ali insculpida, e em variadas situações.

As três construções jurisprudenciais tratadas no presente artigo revelam a busca de significação às figuras mencionadas no referido inciso I. No episódio da discussão sobre a aposentadoria espontânea, o STF afirmou o significado da despedida "sem justa causa", constituindo ela a despedida oposta àquela "com justa causa", ou seja, o tipo de despedida que não se baseia e um fato pré-definido legalmente. No caso da discriminação presumida em relação à doença por estigma social, a jurisprudência acabou articulando um significado ao que seria a despedida "arbitrária", em esforço contra tratamentos discriminatórios em decorrência do estado de saúde de trabalhadores. Por fim, na discussão quanto à "despedida imotivada", STF e TST estão a orquestrar a criação de um procedimento de extinção do contrato que visa reduzir as chances de comportamentos anti-isonômicos e abusivos por parte de empregadores de empresas estatais.

Em comum, as três iniciativas apresentam certo sentido de incompletude. Em todos eles, o fenômeno que se pretendeu regular era mais amplo do que enfoque considerado, já que, em cada oportunidade, o que se buscava era a resolução específica de uma pretensão baseada no alegado direito subjetivo. Para a aposentadoria espontânea, desconsiderou-se a possibilidade de uma regulação que apontasse como arbitrária ou sem justa causa apenas aquelas decorrentes da iniciativa do empregador, ignorando-se por completo as consequências da decisão. No caso da despedida discriminatória presumida, não se considerou que, sob a invocação do princípio da isonomia, acabou-se por criar uma nova realocação do risco social, de questionável conformidade com as regras gerais em vigor. Já no caso da exigência de motivação da despedida para o caso das empresas estatais, não houve inequívoca explicitação do conteúdo da exigência, de forma a possibilitar interpretações no sentido do 
reconhecimento de um garantia de emprego, para a além da garantia de tratamento isonômico buscada e a gerar instabilidade no exame das demissões.

Tal incompletude, infelizmente, será inevitável. Mesmo diante do grande esforço empreendido, é preciso que o próprio Poder Judiciário reconheça que, institucionalmente, ele tem uma gravíssima limitação em seus esforços de densificação de lacunas: o processo judicial, sua única ferramenta de ação.

A construção de diretrizes gerais e abstratas advindas da lei é realizada por meio de um raciocínio dedutivo. Parte-se do geral, o texto legal, para o particular, situação fática de sua aplicação. O Poder Judiciário, por sua vez, quando atua no exercício do preenchimento de lacunas, produz formulações sempre indutivas, por meio do processo judicial, que partem do conjunto das soluções particulares rumo à identificação de um sentido geral. Com isso, será sempre mais árduo que o preenchimento das lacunas seja realizado de forma orgânica. É preciso reconhecer, inbostante todo o desconforto, que o preenchimento de lacunas pelo Poder Judiciário terá sempre mais chances de gerar efeitos colaterais não previstos e não desejados.

Isso quer dizer, portanto, que o exercício judicial do preenchimento de lacunas não pode se entender completo, ainda quando tal preenchimento decorra de intepretação sistemática, envolvendo outros dispositivos constitucionais além daquele cuja regulamentação é preceituada no texto constitucional. Em outras palavras, é preciso que o próprio Poder Judiciário exercite tal poder com a prudência dos sábios, sem ilusões de que sua atividade conduzirá, de forma segura, a um estado geral de melhoria social.

Se é verdade que há muito se afirma, como fez William Bond ${ }^{45}$ em 1896, em capítulo intitulado Judicial legislation, que em certos casos será inevitável o exercício judicial da atividade legiferante, é igualmente verdadeiro que a autoridade reconhecida aos julgadores impõe-lhes o ônus de redobrada atenção, por representarem o último bastião da proteção do Direito. Como anotou Alexander Pekelis, lembrado por Inocêncio Mártires Coelho, “as grandes cláusulas da Constituição americana, assim como as disposições mais importantes das nossas leis fundamentais, não contêm senão uma apelo à honestidade e prudência daqueles a quem é confiada a responsabilidade de sua aplicação" ${ }^{\text {"46. }}$.

\footnotetext{
${ }^{45}$ BONDY, William, Separation of Governmental Powers - in History, in Theory, and in Constitution. New York: Ed. Columbia College, 1896.

${ }^{46}$ MENDES, Gilmar Ferreira; COELHO, Inocêncio Martires; BRANCO, Paulo Gustavo Gonet. Curso de Direito Constitucional. $4^{\mathrm{a}}$ ed. São Paulo: Ed. Saraiva, 2009, p. 162
} 
A longa - e ainda em construção - trajetória do artigo $7^{\circ}$, inciso I, da Constituição nos sugere, portanto, que a par de ser possível que a inação legislativa importe em uma miríade de soluções jurisprudenciais aparentemente autônomas, é preciso que legisladores e operadores permaneçam atentos para identificar os contextos materiais destes direitos. Do contrário, regulações posteriores a conformações de jurisprudência densificadas a partir de valores constitucionais podem ser afirmadas inconstitucionais, por contrariarem o sentido de princípios assentados jurisprudencialmente. Trata-se de risco que pode repercutir negativamente na intenção de elaboração de institutos jurídicos coerentes e orgânicos.

Como bem advertiu Forthoff, citado por Paulo Bonavides, "a superação do positivismo de nenhum modo pode implicar o abandono da positividade do Direito"47.

\section{Referências bibliográficas.}

BARROS, Alice Monteiro. Curso de Direito do Trabalho. São Paulo: Ed. LTr, 2005.

BONAVIDES, Paulo. Curso de Direito Constitucional, 15 a ed. São Paulo: Ed. Malheiros, 2004.

BONDY, William. Separation of Governmental Powers - in History, in Theory, and in Constitution. New York: Ed. Columbia College, 1896.

CANOTILHO, J.J Gomes. Direito Constitucional e Teoria da Constituição. $7^{\mathrm{a}}$ ed. Lisboa: Ed. Almedina, 2003.

CASTRO, Carlos Alberto Pereira de Castro e LAZZARI, João Batista. Manual de Direito Previdenciário, $11^{\mathrm{a}}$ ed. Florianópolis: Ed. Conceito Editorial, 2009.

GARCIA, José Francisco. "Judicial Activism and Accountability". Libertad y Desarrollo, Political Report Series, Nr 1.800, setembro de 2012.

GONÇALVES, Carlos Roberto. Direito Civil Brasileiro, Volume IV, Responsabilidade Civil. $4^{\mathrm{a}}$ ed.

São Paulo: Ed. Saraiva, 2007.

HESSE, Konrad. A Força Normativa da Constituição. Porto Alegre: Ed. Sérgio Antônio Fabris Editor, 1991.

Limites da Mutação Constitucional. In: ALMEIDA, Carlos dos Santos, MENDES, Gilmar Ferreira e COELHO, Inocêncio Mártires (org). Temas fundamentais do Direito Constitucional. São Paulo: Ed. Saraiva, 2009, p. 168.

${ }^{47}$ BONAVIDES, Paulo, Curso de Direito Constitucional, 15a ed. São Paulo: Ed. Malheiros, 2004, p. 285. 
LASSALE, Ferdinand, A Essência da Constituição. Rio de Janeiro: Ed. Lumen Juris, 2001.

MALLET, Estêvão, Igualdade e Discriminação em Direito do Trabalho. São Paulo: LTr, 2013.

MELlO, Celso Antônio Bandeira de, Conteúdo jurídico do princípio da igualdade, $3^{\mathrm{a}}$ Ed. São Paulo: Ed. Malheiros, 2006.

MENDES, Gilmar Ferreira; COELHO, Inocêncio Martires; BRANCO, Paulo Gustavo Gonet, Curso de Direito Constitucional, $4^{\mathrm{a}}$ ed. Ed. Saraiva, 2009.

OST, François, O tempo do Direito. Bauru: Ed. EDUSC, 2005.

POSNER, Richard A. The Economics of Justice. London and Massachussetts: Harvard University Press, 1983.

RAWLS, John. Uma teoria da Justiça. São Paulo: Ed. Martins Fontes, 2000.

STRAUSS, David, The Living Constitution. Coleção "The Inalienable Rights". Oxford-New York: Oxford University Press, 2010.

SUSSEKIND, Arnaldo; MARANHÃO, Délio; VIANNA, Segadas; TEIXEIRA, Lima. Instituições de Direito do Trabalho. São Paulo: Ed. Ltr, 2005.

\section{Decisões judiciais mencionadas:}

Brasil, STF, MI 720/PA, Tribunal Pleno, Rel. Min. Eros Grau, j. 25/10/2007, DJe 31/10/2008.

Brasil, STF, ADI 1.480 MC/DF, Tribunal Pleno, Rel. Min. Celso de Mello, j. 04/09/1997, DJ 18/05/2001.

Brasil, STF, ADI 1.625/DF, Tribunal Pleno, Rel. Min. Maurício Corrêa, pendente de julgamento.

Brasil, STF, ADI-1721/DF, Tribunal Pleno, Rel. Min. Carlos Ayres Britto, j. 11/10/2006, DJe 29/06/2007.

Brasil, STF, RE 589.998/PI, Tribunal Pleno, Relator Min. Ricardo Lewandowski, julgamento dia 20/03/2013. DJe 11/09/2013

Brasil, TST-E-ED-RR-76089/2003-900-02-00, SBDI-1, Rel. Min. Rosa Weber, DJ 30/11/2007.

Brasil, TST-E-RR-366/2000-021-15-00, SBDI-1, Rel. Min. Horácio Senna Pires, DJ $14 / 11 / 2008$. 
Brasil, TRT-3 ${ }^{\text {a }}$ Região, RO-0002074-15.2011.5.03.0040, 6 ${ }^{a}$ Turma, Rel. Desembargador Anemar Pereira Amaral, DJ 22/10/2012.

Brasil, TST-RR-752-05.2010.5.03.0101, 6 ${ }^{\mathrm{a}}$ Turma, Rel. Min. Aloysio Corrêa da Veiga, DJ $12 / 04 / 2013$.

Brasil, TST-RR-1996700-79.2006.5.09.0011, 7 ${ }^{\mathrm{a}}$ Turma. Rel ${ }^{\mathrm{a}}$ Min $^{\mathrm{a}}$ Delaíde Miranda Arantes, DJ 16/08/2013.

Artigo recebido em 10 de setembro de 2013. Artigo aprovado para publicação em 16 de setembro de 2013.

DOI: $10.11117 / 1982-4564.06 .18$ 